The Chittagong Univ. J. B. Sci., Vol. 5(1 \&2):09-17, 2010.

\title{
HISTOPATHOLOGY OF STOMACH TISSUE OF CATFISH MAGUR, CLARIAS BATRACHUS L. UNDER CHROMIUM, CADMIUM AND MERCURY STRESS
}

\author{
SHAWKAT ARA BEGUM, QAMAR BANU AND BAHARUL HOQUE*
}

Department of Zoology, University of Chittagong, Chittagong-4331, Bangladesh

\begin{abstract}
Histopathological effect of three heavy metals- cadmium, chromium and mercury on the stomach tissue of catfish Magur, Clarias batrachus L. was studied under laboratory condition. Pathological symptoms due to metal stress showed significant damage of mucosal epithelium, hypertrophied epithelial cells with pyknotic nuclei and clear cytoplasm, separation of epithelium, separation of damaged digestive gland cells from the basement membrane, and vacuolation and rupture in submucosa and muscularis layer. Damages of the mucosal epithelial and gastric gland cells due to $\mathrm{Cr}$ treatment were significant while the epithelial hypertrophied cells undergone further deterioration due to $\mathrm{Cd}$ and $\mathrm{Hg}$ exposure. Blood vessels were hyperemic and necrosed in $\mathrm{Cd}$ and clumping of blood cells in the lamina propria beneath the mucosal epithelium in the fish exposed to $\mathrm{Cr}$.
\end{abstract}

Key words: Heavy metal, histopathology, hypertrophy, necrosis.

\section{INTRODUCTION}

Agricultural, industrial, and domestic effluents generally contain a wide variety of organic and inorganic pollutants including heavy metals that are invariably discharged into various waterbodies without proper treatments (Pandey et al. 2003). Such contamination changes water quality and the organisms therein may pose serious problem such as deseases, structural alterations, even death. Heavy metals in water are toxic and detrimental to agriculture, animal, and human (Chhatwal et al. 1992). Generally, they are present at a very low concentration in nature, but it goes up in the polluted environment. Once dispersed in the biosphere, heavy metals can not be recovered or degraded. They become free in nature, accumulate in agricultural fields, and in organisms that live within (Badsha and Goldspink 1982, Singh 1988) causing reduction of biodiversity, poor production, sometimes even hyper-production, and many other causal impacts.

Different heavy metals have been detected in many waterbodies of Bangladesh at relatively higher concentrations (Agarwal 1998, Majid et al. 2003,

*Corresponding author:

$-3$ 
Quraishi and Akhter 2005). The present work is an attempt to investigate the toxic effect of three heavy metals - cadmium, chromium and mercury on stomach tissue of the freshwater catfish Clarias batrachus L. under laboratory condition.

\section{MATERIALS AND METHODS}

Fresh and live Magur (average length $16 \pm 3 \mathrm{~cm}$ and weight $70 \pm 5 \mathrm{~g}$ ) was bought from Chittagong city market and conditioned for 7 days in $25 \mathrm{~L}$ aquarium in non chlorinated tap water. The fishes were supplied with animal food sources (oligochaetes, prawn and small pieces of Harpodon nehereus) once in a day. Water was changed at $24 \mathrm{~h}$ interval. For experimental purposes, 15 fish in each 25L aquarium was exposed to each sub lethal conc. of heavy metals $(\mathrm{Cd}-9 \mathrm{ppm}$, $\mathrm{Cr}-12 \mathrm{ppm}$ and $\mathrm{Hg}-0.3 \mathrm{ppm}$ ) over 28 days periods and a control without heavy metal.

Method of Humason (1961) was followed for histopathological study. At the end of the exposure period stomach from the treated as well as control fish were isolated, cleaned with physiological saline solution, cut into pieces and fixed in freshly prepared Bouin's fixative. After 24 hours, tissues were preserved using $70 \%$ alcohol. For histological slide preparation, tissues were dehydrated in graded alcohol, cleared in benzene and embedded in paraffin. Thin sections $(3-5 \mu)$ were cut by a rotary microtome, double stained by eosin-haematoxylin, mounted with DPX for examination under microscope. Photomicrographs were taken by Ricoh $35 \mathrm{~mm}$ SLR camera fitted with a microscope.

\section{RESULTS AND DISCUSSION}

Histologically the stomach wall of Magur (control specimens) exhibited four general layers that were characteristic of the entire digestive tract- mucosa, submucosa, muscularis externa and serosa (Plate 1). The innermost layer mucosa was lined by simple columnar epithelium extending into the gastric pits. The gastric glands were lined with a single layer of cells rested on a thin basement membrane. The submucosa was made up of loose connective tissue and contained blood vessels and lymph spaces. The stomach exhibited broad mucosal folds subdivided into primary and secondary folds. These folds also involved the lamina propria and submucosa.

The observed pathological changes of the stomach were: damage of the mucosal epithelial layer which was detached at places from the basal layer, sloughed off epithelial cells and mucous in the lumen of the stomach, hypertrophied epithelial cells of the mucosa and gastric glands with pyknotic 
nuclei and clear cytoplasm, separation of the gastric gland cells from the basement membrane forming cluster, rupture in submucosa and sometimes in muscularis layer, hyperemic blood vessels, and presence of scattered blood cells in the submucosa and muscularis layer or all over the entire stomach tissue (Plates 2-8). Similar pathological changes have been observed in the stomach of different species of fishes due to toxic effect of heavy metal and other pollutants (Singh 1983, Virk et al. 1987, Begum et al. 2001).

Konar (1975) reported that phosphamidon completely degenerate the epithelial cells of the mucous membrane of stomach of $H$. fossilis. Amminiukutty and Rege (1978) observed swelling, vecuolation and pyknosis of the mucosal epithelial cells of stomach in Gymnocorymbus ternetzi exposed to organic toxicant Thiodan and Agallol ' 3 '. The most notable histopathological change observed in the present work was the damage of mucosal epithelial cells and gastric gland cells of the stomach. Such damage was recognizable from the hypertrophied cells which were pyknotic with clear cytoplasm in $\mathrm{Cr}$ exposed fish (Plates 3, 4). The situation was more severe with $\mathrm{Cd}$ and $\mathrm{Hg}$ exposed fish where the epithelial cells were highly damaged and even some were completely ruptured (Plates 2, 4, 6, 7). The gastric gland cells were damaged to form a cluster of cells in the middle of gland separating off from the basement membrane. Separation of mucosal membrane and sloughing off of the epithelial cells or mucous in the stomach lumen were also observed. All these observations are consistent with that of Roberts (1989) who reported that the gut mucosa in acute toxic conditions of bacterial, viral or chemical origin may undergo lift off en masse. The hypertrophy of the epithelial cells of the mucosal membrane and digestive glands is known to be a protective mechanism that an animal usually shows in response to chemical or toxic stresses. The purpose of the response is to provide, at the site of an assault, the cells and tissue fluids that are best able to act to preserve homeostasis (Roberts 1989). However, under severe toxic conditions hypertrophied cells undergo rupture and damage as found in the present findings when exposed to $\mathrm{Cd}$ and $\mathrm{Hg}$.

Vacuolation of submucosa and muscularis layer has been reported from different test cases (Virk et al. 1987, Saxena and Sinha 1997, Begum et al. 2001, Sharma et al. 2001). In the present investigation, conspicuous spaces and ruptures in the lamina propria, submucosa and muscularis layers of stomach were observed in test fish when exposed in most of the heavy metals (Plates 3, 5, 7, 8). These layers were also haemorrhagic as revealed by the presence of excess blood cells. Blood vessels were hyperemic and some times necrosed as observed in the 
stomach tissue of $\mathrm{Cd}$ treated Magur. Besides, the stomach tissue showed clumping of blood cells in the lamina propria just beneath the mucosal epithelium in the fish exposed to chromium (Plate 4). According to Roberts (1989) the submucosal reactions are usually a reflection of the mucosal response and are generally oedematous or haemorrhagic. Findings of the present study are consistent with the observations stated above.

\section{REFERENCES}

AMMINIKUTTY, K. C. AND REGE, M. S. 1978. Acute and chronic effect of thiodan $35 \mathrm{E} \mathrm{C}$ and Agallol ' 3 ' on kidney, stomach and intestine of Gymnocorymbus ternetzi Bonlenger. Indian J. Exptl. Biol. 16: 202-206.

AGARWAL, G. D. 1998. Industrial Pollution- An overview. In: Bangladesh Environment: Facing the 21st century. (ed. Gain, P.). SEHD, Dhaka, pp.167.

BADSHA, K. S. AND GOLDSPINK, C. R. 1982. Preliminary observations on the heavy metal content of four species of fresh water fish in NW England. J. Fish. Biol. 21: 251-256.

BEGUM, S. A., KHANAM, F. AND HOQUE, B. 2001. Effects of chromium on histological structures of different organs of Clarias gariepinus (Burchel). The Chittagong Univ. J. Sci. 25(1): 1-10.

CHHATWAL, G. R., MEHRA. M.C., SATAKE, M., KATYAL, T., KATYAL, M. AND NAGATHRO, T. 1992. Encyclopedia of environtal pollution and its control. Vol. II, Water pollution. Anmol Publications. New Delhi, 79-254 pp.

HUMASON, L. G. 1961. Animal tissue technique. $2^{\text {nd }}$ ed. W. H. Freeman and Company. San Francisco, U.S.A. 558 pp.

KONAR, S. K. 1975. Pesticides and aquatic ecosystems. Indian J. Fish. 22(1, 2): $80-85$.

MAJID, M. A., RAHMAN, I. M. M., AND BHUIYAN, M. I. H. 2003. Environmental impact assessment of the effluents from Kalurghat industrial area of Chittagong on the Karnaphuli river water. The Chittagong Univ. J. Sci. 27 (1 \& 2): 61-69.

PANDEY, S., PARVEZ, S., SAYEED, I., HAQUE, R., BIN- HAFEEZ, B. AND RAISUDDIN, S. 2003. Biomarkers of oxidative stress: a comparative study of river Yamuna fish Wallago attu (Bl. \& Schn.). Sci. Total Environ. 309: 105-115.

QURAISHI, S. B. AND AKHTER, S. 2005. Study of concentration of some toxic and essential elements in marine water, sediment and their impact on marine biota. J. Bangladesh Acad. Sci. 29(2): 163-171. 
ROBERTS, R.J. 1989. Fish pathology. $2^{\text {nd }}$ ed. Balliere Tindall. London, 21pp.

SAXENA, M. AND SINHA, S. 1997. Histopathological changes in the stomach and liver of Channa punctatus (Bloch) induced by Rogor, In: Recent advances in Freshwater Biology. K.S. Rao (ed.). Anmol Publications Pvt. Ltd. 1: 193-198.

SHARMA, R.R., PANDEY, A.K. AND SHUKLA, G.R. 2001. Histopathological alterations in fish induced by pesticides toxicity. Aquacult. 2(1): 31-43.

SINGH, V.P. 1988. Toxic models in soil-plant systems with special reference to cadmium. Int. J. Ecol. Environ. Sci. 14: 185-197.

SINGH, Y.N. 1983. Histopathological changes induced by a heavy metal compound copper sulphate on a freshwater fish Colisha fasciata. Proc. Nat. Acad. Sci. 53BO: 213-216.

VIRK, S., KAUR, K. AND KAUR, S. 1987. Histopathological and biochemical changes induced by endrin and carbaryl in the stomach, intestine and liver of Mystus tengara. Indian J. Ecol. 14 (1): 14-20.

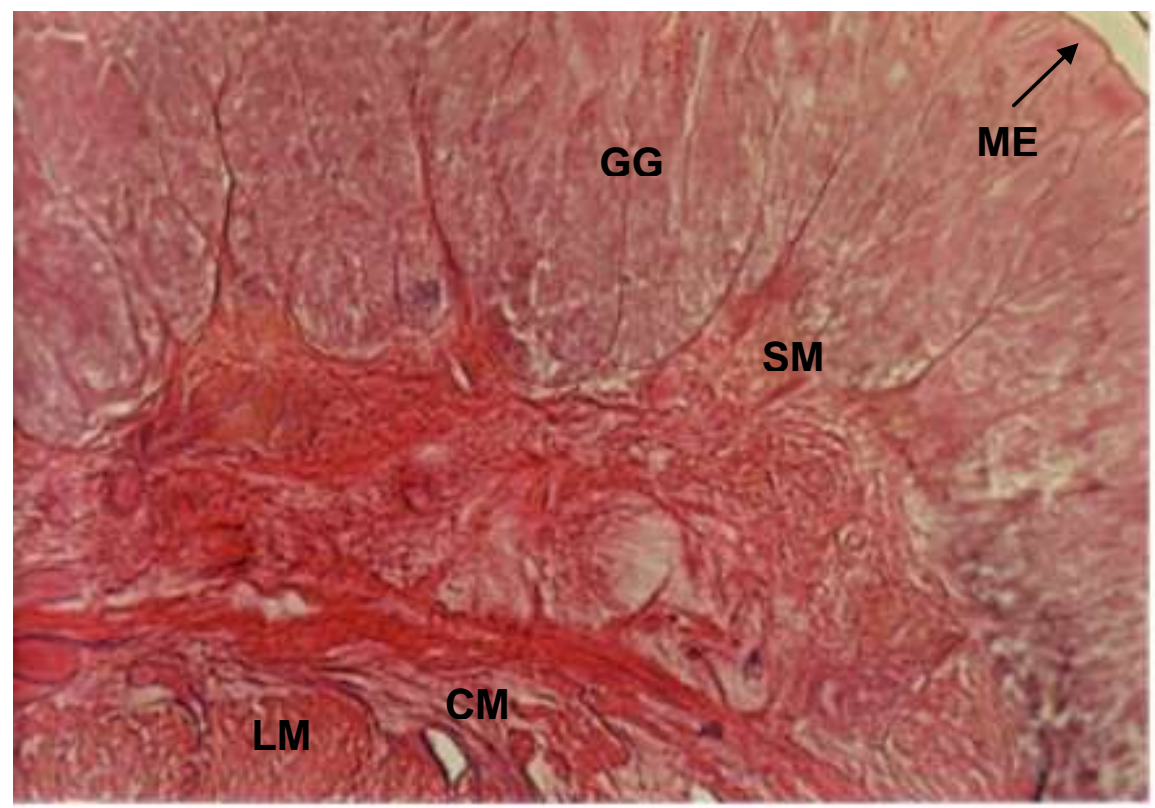

PLATE 1: PHOTOMICROGRAPH OF THE SECTION OF STOMACH OF CONTROL SPECIMEN OF CLARIAS BATRACHUS SHOWING MUCOSAL EPITHELIUM (ME) OF MUCOSAL MEMBRANE, GASTRIC GLAND (GG), SUBMUCOSA (SM), AND CIRCULAR MUSCLE (CM) AND LONGITUDINAL MUSCLE (LM) OF THE MUSCULARIS LAYER. $\mathrm{H} \& \mathrm{E} 10 \times 40$. 
BEGUM ET AL.

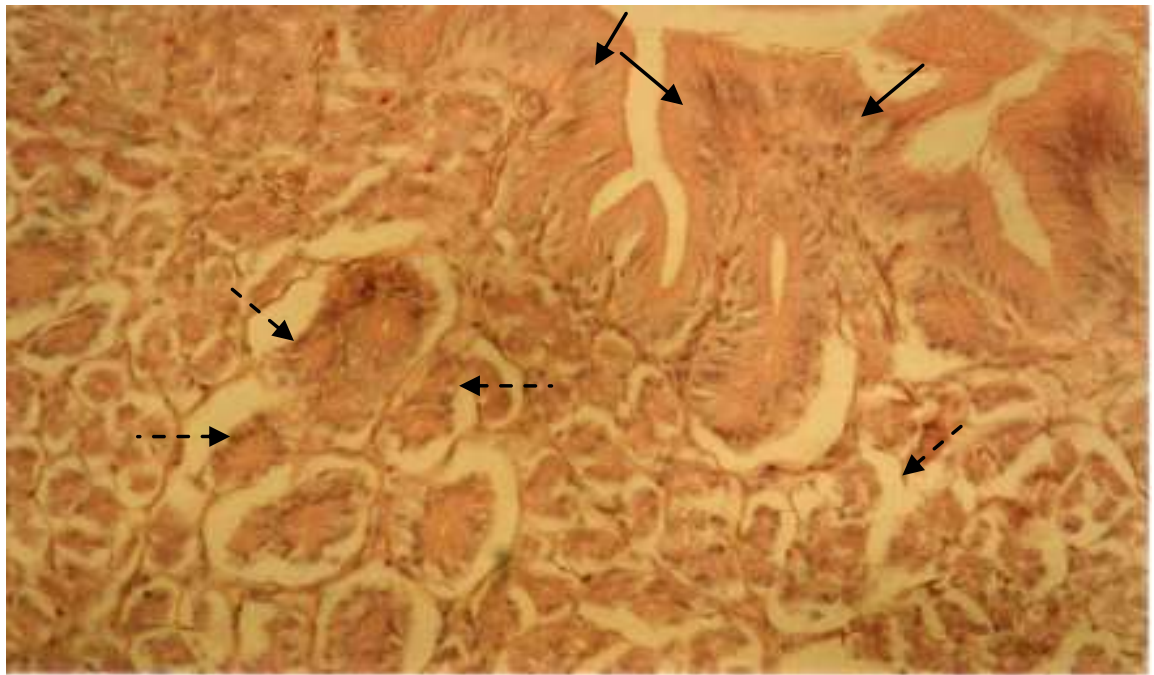

PLATE 2: PHOTOMICROGRAPH OF THE SECTION OF STOMACH OF CD-EXPOSED CLARIAS BATRACHUS SHOWING SWOLLEN EPITHELIAL CELLS (ARROW) OF MUCOSA WITH HYALINE CYTOPLASM AND PYKNOTIC NUCLEI, DISINTEGRATED GLANDULAR EPITHELIAL CELLS SEPARATED FROM THE BASEMENT MEMBRANE AND AGGREGATED IN THE MIDDLE (BROKEN ARROW). H\&E 10×40.

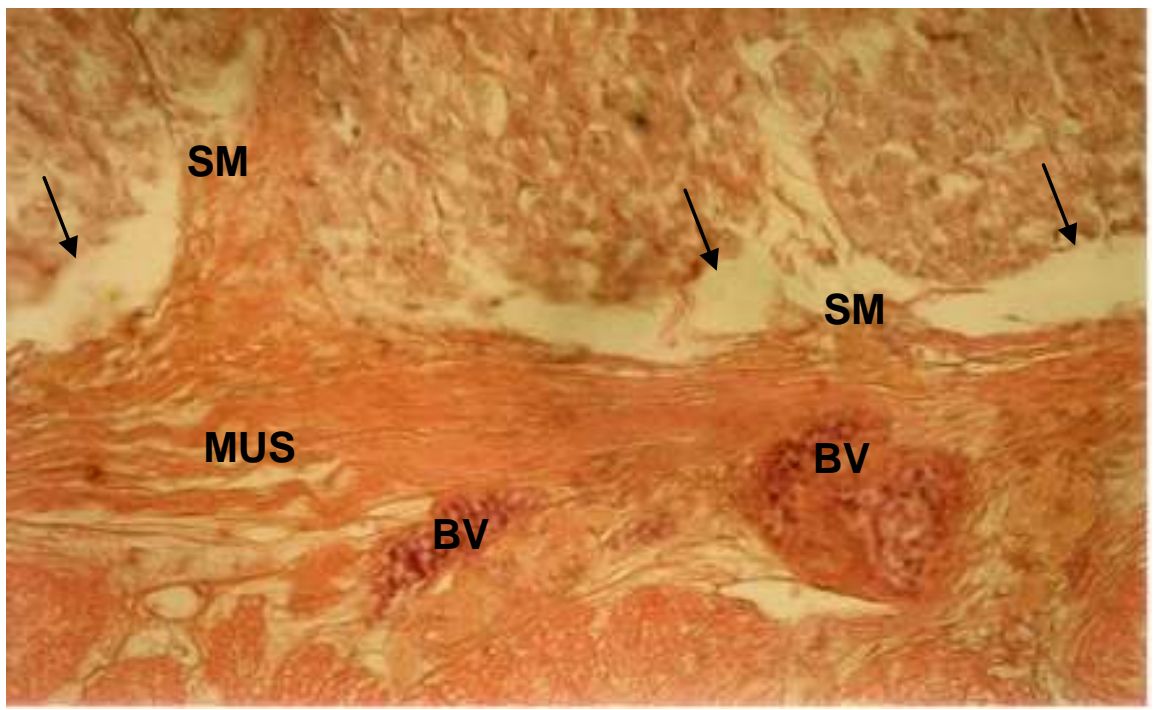

PLATE 3: PHOTOMICROGRAPH OF THE SECTION OF STOMACH OF CD-EXPOSED CLARIAS BATRACHUS SHOWING SEPARATION OF MUCOSAL LAYER FROM THE BASAL LAYER (ARROW); DISTORTED SUBMUCOSA (SM) AND MUSCULRIS (MUS), AND HYPEREMIC BLOOD VESSELS (BV). H\&E 10×40. 
HISTOPATHOLOGY OF MAGUR STOMACH TISSUE UNDER Cr, Cd AND Hg STRESS

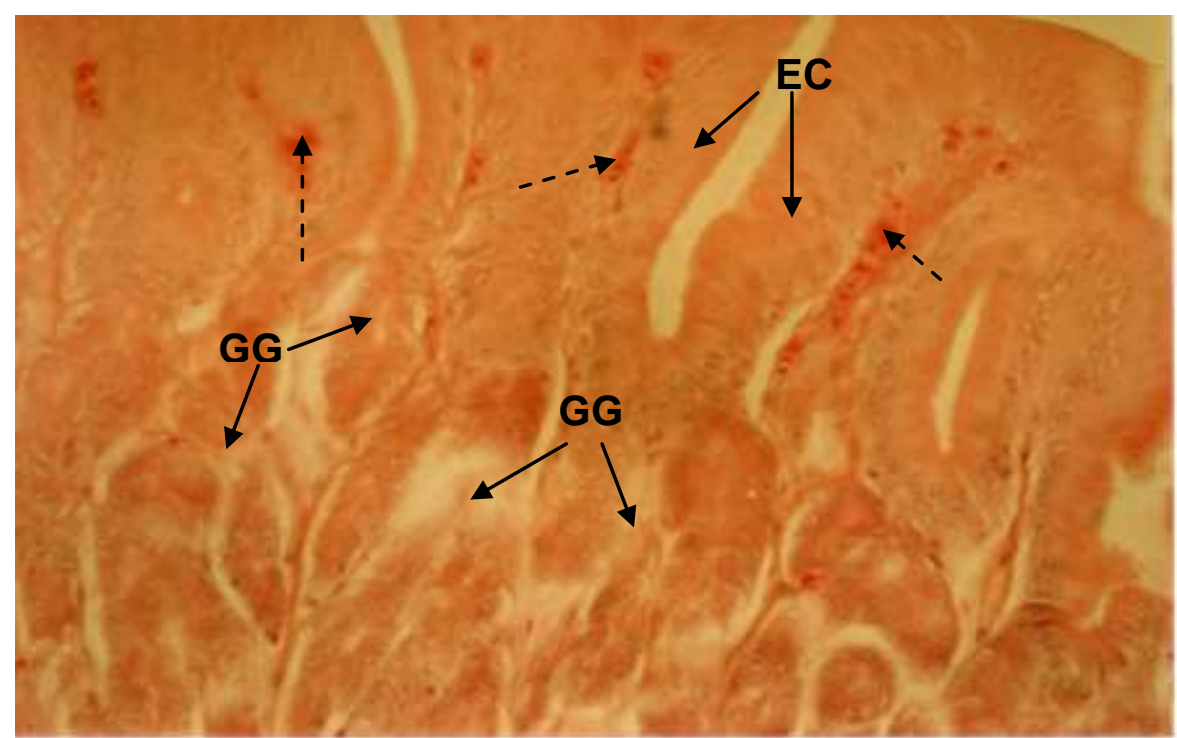

PLATE 4: PHOTOMICROGRAPH OF THE SECTION OF STOMACH OF CR-EXPOSED CLARIAS BATRACHUS SHOWING HYPERTROPHIED MUCOSAL EPITHELIAL CELLS (EC) WITH CLEAR CYTOPLASM AND SWOLLEN PYKNOTIC NUCLEI; DEGENERATION OF GASTRIC GLAND CELLS (GG) AND CONGESTION OF BLOOD IN THE LAMINA PROPRIA BENEATH THE MUCOSAL EPITHELIA (ARROW). H\&E 10×40.

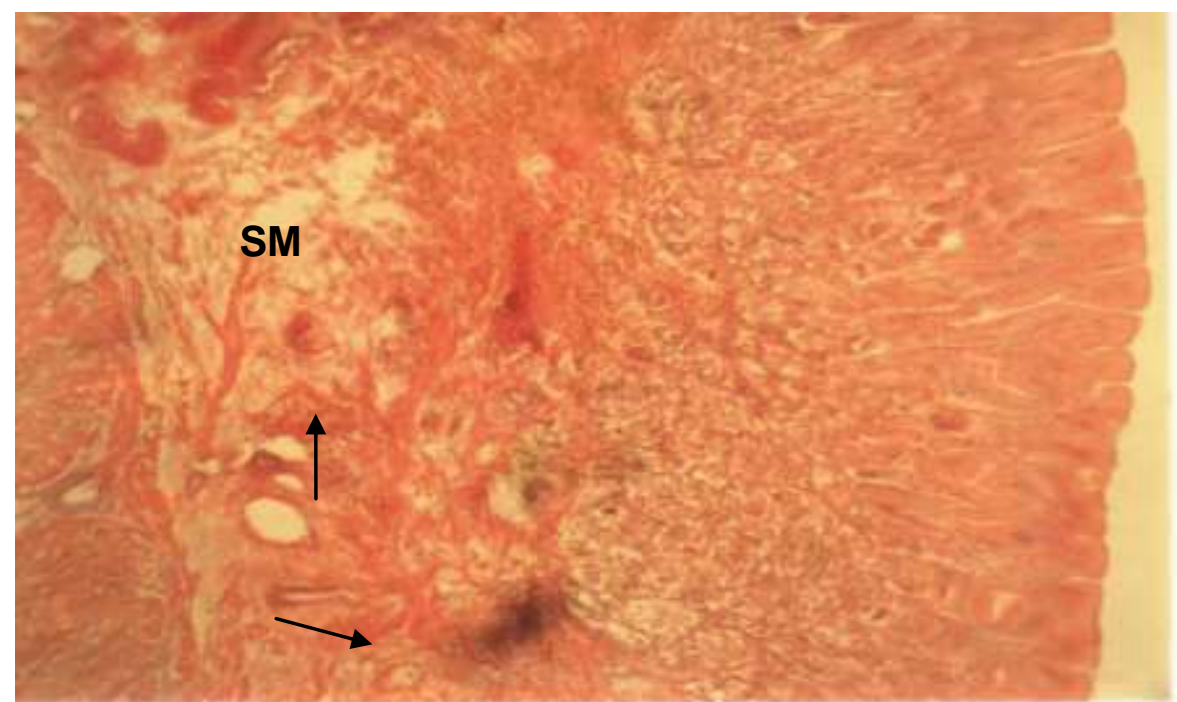

PLATE 5: PHOTOMICROGRAPH OF THE SECTION OF STOMACH OF CR-EXPOSED CLARIAS BATRACHUS SHOWING VACUOLATION AND RUPTURE IN THE SUBMUCOSA (SM), AND HYPEREMIC BLOOD VESSELS (ARROW). H\&E 10×10. 
BEGUM ET AL.

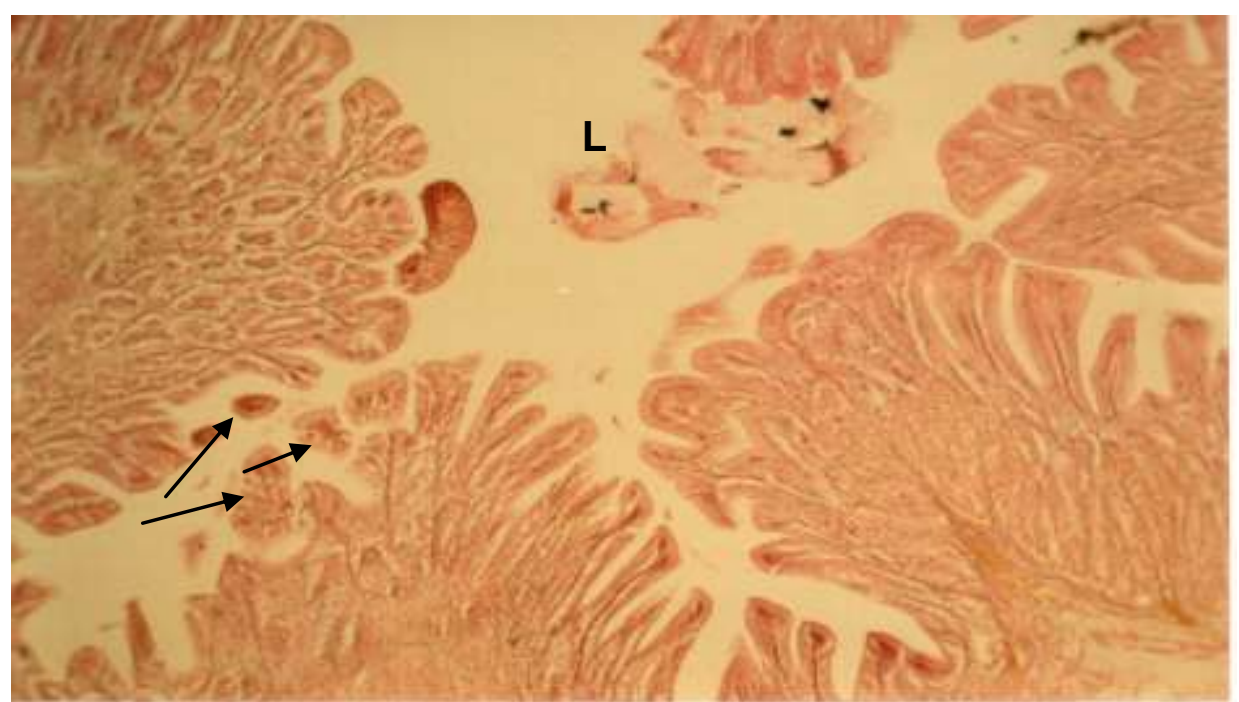

PLATE 6: PHOTOMICROGRAPH OF THE SECTION OF STOMACH OF HG-EXPOSED CLARIAS BATRACHUS SHOWING RUPTURE AND SEPARATION OF MUCOSAL EPITHELIUM (ARROW); AND SLOUGHED OFF EPITHELIAL CELLS AND MUCOUS IN THE LUMEN (L). H\&E $10 \times 10$.

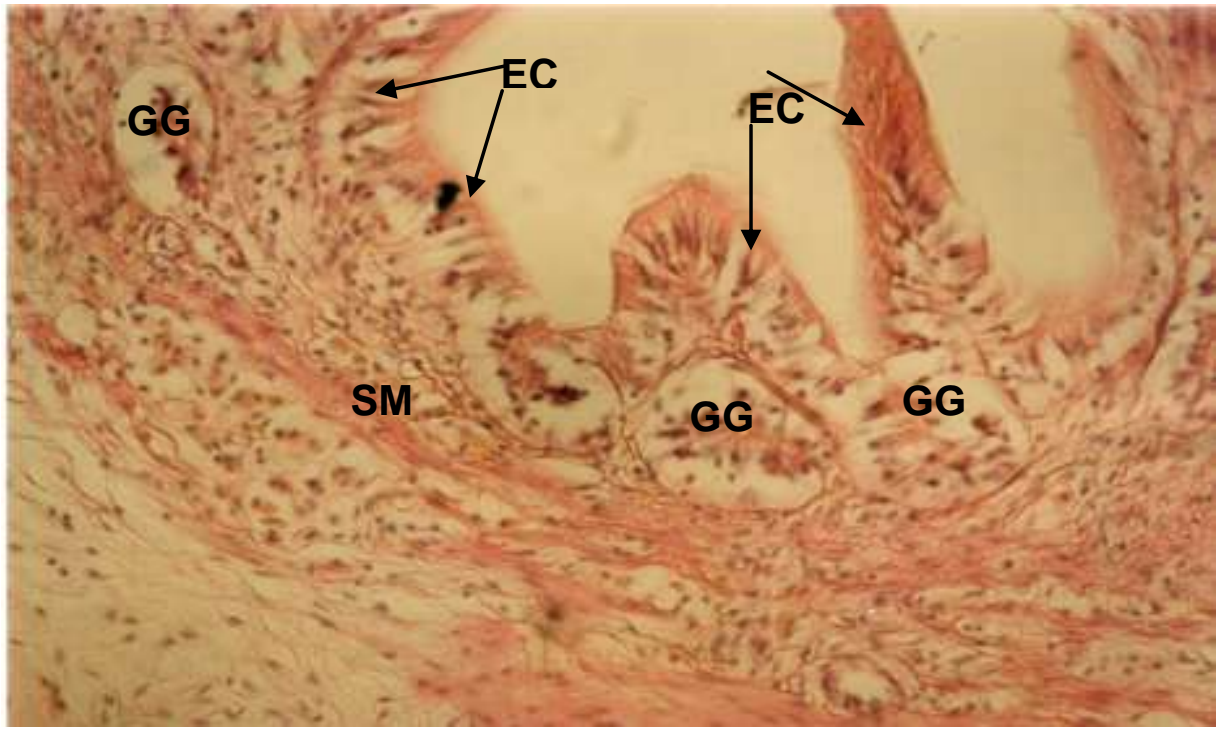

PLATE 7: PHOTOMICROGRAPH OF THE SECTION OF STOMACH OF HG-EXPOSED CLARIAS BATRACHUS SHOWING HIGHLY DAMAGED EPITHELIAL CELLS OF THE MUCOSA (EC), COMPLETE DEGENERATION OF GASTRIC GLAND CELLS FORMING CLUSTER IN THE MIDDLE (GG), DEGENERATION OF SUBMUCOSAL CONNECTIVE TISSUE (SM) AND PRESENCE OF EXCESSIVE BLOOD CELLS ALL OVER THE TISSUE. $\mathrm{H} \& \mathrm{E} 10 \times 40$. 
HISTOPATHOLOGY OF MAGUR STOMACH TISSUE UNDER Cr, Cd AND Hg STRESS

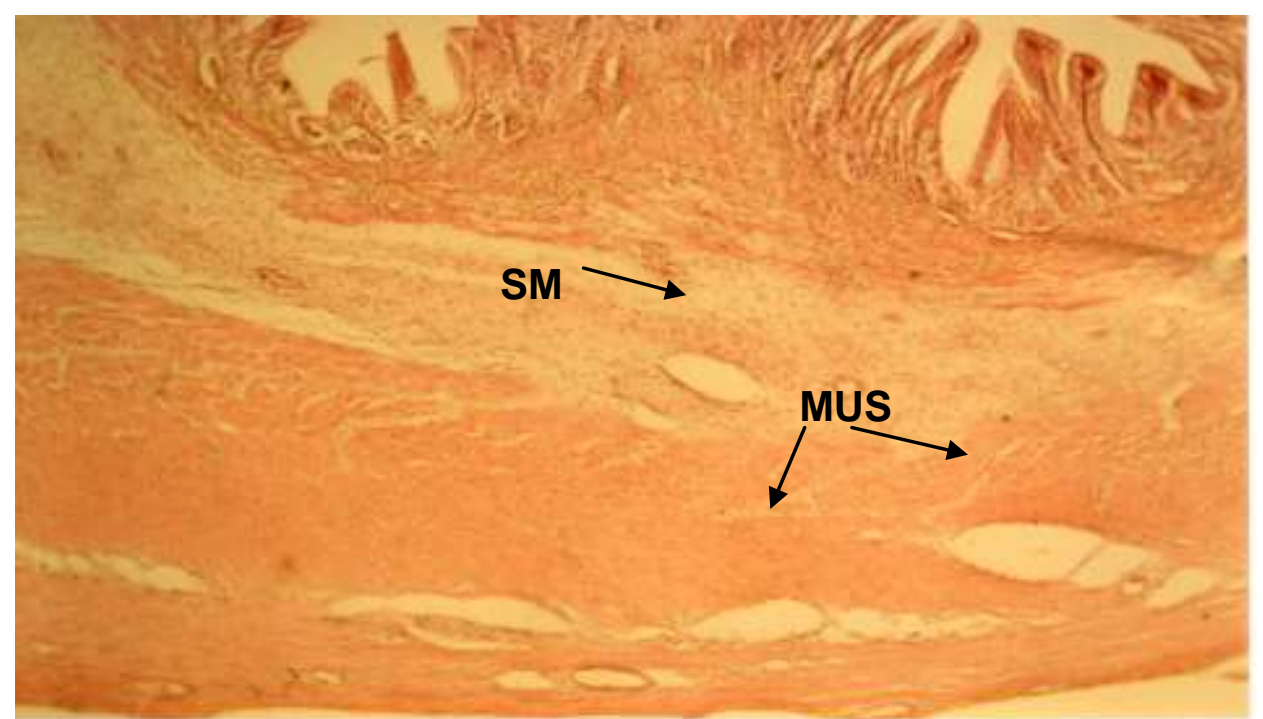

PLATE 8: PHOTOMICROGRAPH OF THE SECTION OF STOMACH OF HG-EXPOSED CLARIAS BATRACHUS SHOWING RUPTURES (ARROW) IN SUBMUSCOSA (SM) AND MUSCULARIS LAYER (MUS). H\&E. 10×10.

Manuscript received on 6. 12. 2009; Accepted on 29.9.11

The Chittagong University Journal of Biological Sciences, Vol. 5 (1 \& 2). Page No:09-17 